Published in final edited form as:

Crit Rev Oncol Hematol. 2007 November ; 64(2): 159-171.

\title{
Role of erythropoietin in the brain
}

\author{
Constance Tom Noguchi, Pundit Asavaritikrai, Ruifeng Teng, and Yi Jia \\ Molecular Medicine Branch, National Institute of Diabetes \& Digestive \& Kidney Diseases, National \\ Institutes of Health, Department of Health and Human Services, Bethesda, MD 20892-1822 USA
}

\begin{abstract}
Multi-tissue erythropoietin receptor (EPO-R) expression provides for erythropoietin (EPO) activity beyond its known regulation of red blood cell production. This review highlights the role of EPO and EPO-R in brain development and neuroprotection. EPO-R brain expression includes neural progenitor cells (NPC), neurons, glial cells and endothelial cells. EPO is produced in brain in a hypoxia sensitive manner, stimulates NPC proliferation and differentiation, and neuron survival, and contributes to ischemic preconditioning. Mice lacking EPO or EPO-R exhibit increased neural cell apoptosis during development before embryonic death due to severe anemia. EPO administration provides neural protection in animal models of brain ischemia and trauma, reducing the extent of injury and damage. EPO stimulation of endothelial cells contributes to neuroprotection and is of particular importance since only low levels of EPO appear to cross the blood-brain barrier when administered at high dose intravenously. The therapeutic potential of EPO for brain ischemia/trauma and neurodegenerative diseases has shown promise in early clinical trial and awaits further validation.
\end{abstract}

\section{Keywords}

Erythropoietin; receptor, neuroprotection; blood-brain barrier; ischemic preconditioning; brain ischemia; neurogenesis, endothelium

\section{Introduction}

Erythropoietin (EPO) acts primarily to stimulate erythroid cell production supporting the survival, proliferation and differentiation of erythroid progenitor cells. In addition to hematopoietic cells, expression of the EPO receptor (EPO-R) and EPO response are observed in other cell types including endothelial and neural cells [1-4]. Mice with targeted deletion of EPO or EPO-R lack definitive erythropoiesis and mature erythrocytes, and die in utero [5,6]. These mice also exhibit increased apoptosis in brain prior to the severe anemia, raising the possibility that beyond EPO requirement for production of mature red blood cells, EPO signaling may contribute to normal brain development $[7,8]$. In addition to EPO production in fetal liver and adult kidney, EPO is produced in brain, in astrocytes and neurons [9-12]. Local production of endogenous EPO in brain in a hypoxia dependent manner further suggests that EPO may act in a paracrine or autocrine manner to provide neuroprotection. Analogous to its activity in erythroid progenitor cells, EPO can stimulate the survival and proliferation of neural progenitor cells (Table 1). EPO neuroprotection in animal models of brain ischemia/trauma raise the possibility for EPO therapy in brain injury/disease.

Corresponding author: Constance Tom Noguchi, Ph.D. Chief, Molecular Cell Biology Section Molecular Medicine Branch, NIDDK National Institutes of Health Building 10, Room 9N307 10 CENTER DR MSC-1822 Bethesda, MD USA 20892-1822 U.S.A. Tele: 001-301-496-1163 FAX: 001-301-402-0101 cnoguchi@helix.nih.gov.

Publisher's Disclaimer: This is a PDF file of an unedited manuscript that has been accepted for publication. As a service to our customers we are providing this early version of the manuscript. The manuscript will undergo copyediting, typesetting, and review of the resulting proof before it is published in its final citable form. Please note that during the production process errors may be discovered which could affect the content, and all legal disclaimers that apply to the journal pertain. 


\section{EPO-R in non-hematopoietic cells}

EPO-R is expressed in progenitor cells from hematopoietic, endothelial, skeletal muscle and neural tissues [1,4,12-14]. While EPO-R expression is down regulated during differentiation of erythroid cells and myoblasts and is not expressed on mature red blood cells or skeletal muscle, EPO-R expression persists in select vascular endothelial cells and mature neurons. An EPO-R transgene driven by the EPO-R promoter as well as an EPO-R transgene restricted to erythroid cell expression are able to rescue mice that lack EPO-R expression $[15,16]$. The absence of gross morphologic defects in mice with EPO-R expression only in hematopoietic cells [16] indicates that further study is necessary to assess normal development and function of brain and other tissue. For example, examination of endothelial cell function in these animals demonstrated impaired ability to mobilize endothelial progenitor cells and increased sensitivity to hypoxia-induced pulmonary hypertension [17]. Although the role of endogenous EPO in development, tissue maintenance and repair of non-hematopoietic tissue is uncertain, increasing evidence from in vitro cell studies and from in vivo animal models suggests that EPO stimulation of progenitor cell proliferation and/or prevention of apoptosis may be useful in selective ischemic or stress events in other tissues or neurodegenerative diseases $[4,12,18]$.

\subsection{EPO activation of JAK2 in multiple tissues}

In erythroid progenitor cells, EPO binds to EPO-R, resulting in activation of the JAK2 and downstream signal transduction pathways including STAT5, PI3 kinase and MAPK [19,20]. EPO-R protein in erythroid cells has no intrinsic enzymatic activity and consists of an extracellular domain and a cytoplasmic domain, each spanning about 230 amino acids, and a single transmembrane domain. This mature erythroid form of EPO-R is also found in other cells exhibiting EPO response such as endothelial and neural cells $[1,3]$. Neural cells exhibit activation of the JAK2/STAT5 and other signal transduction pathways as well as activation of $\mathrm{NF}-\kappa \mathrm{B}$ signaling pathways $[7,21,22]$. The multi-tissue distribution of EPO-R and EPO response suggest that rather than being instructive for erythroid differentiation, EPO may function more generally to provide proliferative and protective/survival activity during erythropoiesis and contribute to other select tissue development, maintenance and/or repair.

\subsection{EPO-R in Brain}

EPO-R brain expression has been observed during development and adulthood in human and non-human primates and other mammals [10,23-26]. In the developing mouse brain during mid gestation, EPO-R localizes in the neural tube in the neuroepithelium that contains proliferating neuroprecursors $[8,23]$. The high level of EPO-R expression in the neural tube at E10.5 is comparable to that of adult hematopoietic tissue. Brain expression then markedly decreases with development by several orders of magnitude to modest levels by birth and persists at low levels through adulthood [23]. Direct binding of I ${ }^{125}$ labeled EPO localized EPO binding sites to specific adult brain regions including the hippocampus, cortex and midbrain in mouse, and EPO-R expression in adult brain was detected in human in analogous regions and in monkey [10,27]. Expression of EPO-R in brain particularly in the embryonic stage suggests a role for EPO in brain development and/or tissue maintenance.

Cultures of rat embryonic hippocampal and cortical neurons demonstrated EPO-R expression and EPO protection from glutamate neurotoxicity, and EPO increased survival of embryonic neurons in the absence of trophic factors [3,7]. Hypoxia induces EPO-R expression in neuronal cells and increases sensitivity to EPO [7,28], although transcription of the EPO-R gene does not appear to be directly regulated by hypoxia inducible factor (HIF). Furthermore, EPO treatment provided protection from hypoxia induced cell death in embryonic and postnatal hippocampal neuron cultures [7,29]. In addition to neurons, EPO-R is expressed in astrocytes and microglia [30]. In erythroid cells EPO induces the erythroid transcription factor, GATA-1, 
and GATA-1 can transactivate EPO-R expression [20,31]. In neural NT2 cells the GATA motif in the EPO-R promoter is required for active transcription and the promoter can be

transactivated by GATA-3, a transcription factor required for brain development [7,32]. Furthermore, while EPO induces GATA-1 in erythroid progenitor cells, EPO induces GATA-3 in neural cells. During erythropoiesis, EPO induces a high level of EPO-R expression in CFUE. In humans, EPO-R expression in adult bone marrow, the primary site of erythropoiesis, is two orders of magnitude greater than in adult brain [31]. High levels of EPO-R expression in erythroid progenitor cells favors efficient splicing of EPO-R transcripts while the lower level of EPO-R expression in neural or brain cells yields both the mature erythroid form of EPO-R mRNA as well as other inefficiently processed forms [31,33]. Nevertheless, EPO-R in neurons is functional and up regulation of EPO-R expression increases EPO response.

EPO-R is a type I cytokine receptor with a single transmembrane domain that lacks an intrinsic tyrosine kinase domain. In the absence of EPO, EPO-R can form a symmetric inactive homodimer complex on the cell surface mediated largely by the EPO-R transmembrane domains while the cytoplasmic domains can associate with the Janus family tyrosine kinase protein JAK2 [34]. EPO acts by binding to the EPO-R homodimer. EPO binding changes the conformation of the EPO-R, activates phosphorylation activity of JAK2 and phosphorylation of JAK2 and EPO-R, that results in signal transduction involving STAT5, PI3 kinase, MAPK and other signaling molecules $[19,20]$. Expression of the mature erythroid form of EPO-R extends beyond the hematopoietic system and includes endothelium and embryonic and adult brain $[1,23]$. EPO-R expression in brain appears on various cell types such as mesenchephalic (midbrain), hippocampal and cortical neurons, astrocytes, oligodendrocytes and brain capillary endothelial cells $[3,30,33]$.

Mice overexpressing EPO in brain were useful in demonstrating the requirement for JAK2 activation of ERK-1/-2 and AKT pathways in providing neuroprotection in the middle cerebral artery occlusion model for ischemic brain that was associated with increased Bcl- $\mathrm{X}_{\mathrm{L}}$ [35]. In specific studies of neuronal cells, EPO treatment of primary hippocampal neurons increases activation of AKT, phosphorylation of Bad, an AKT downstream substrate, and maintains mitochondrial membrane potential preventing the release of cytochrome $\mathrm{c}$ and caspase 1,3 and 8 - like activities [36]. Inhibition of AKT partially reduces EPO neuroprotection, suggesting additional participation of other signaling pathways in EPO neuroprotection. Cultures of cerebrocortical neurons show that EPO activation of JAK2 also results in IאB (inhibitor of NF$\kappa \mathrm{B})$ phosphorylation, translocation of NF- $\mathrm{KB}$ (p65 subunit) to the nucleus allowing for

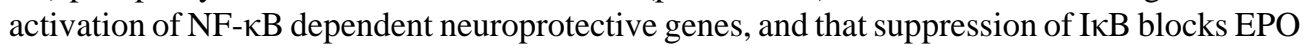
neuroprotection [21]. In a model system using a chimera prolactin/EPO receptor with the prolactin binding extracellular and EPO-R cytoplasmic domains expressed in neuroblastoma cells, EPO-R signaling resulted in strong activation of STAT5 and PI 3 kinase/AKT that were required for neuroprotection, as well as MAPK/ERK-1/-2 [37]. In this chimera prolactin/EPO receptor model, EPO-R signaling also induced a modest accumulation of NF- $\mathrm{KB}$ (p65) in the nucleus compared with the activation of STAT5, PI 3 kinase/AKT and MAPK. As in erythroid progenitor cells, EPO binding to its receptor on neuronal cells stimulate JAK2 and activates a number of signal transduction pathways that promote cell survival (Figure 1).

\section{EPO production in Brain}

EPO expression in fetal liver and adult kidney is hypoxia inducible regulated via the hypoxia response element in the $3^{\prime}$ region of the EPO gene and reporter genes exhibit transactivation by the dimeric hypoxia-inducible factor-1 (HIF-1) [38]. In neural tissue, EPO is also expressed in astrocytes and neurons and is hypoxia inducible, increasing by more than 100 fold in astrocytes incubated under hypoxic conditions [10]. In intact brain, EPO expression is detected in human embryonic brain and biopsies from human adult hippocampus, amygdala and 
temporal cortex, and in various areas in brain of monkey. Hypoxia induction of endogenous brain EPO is also observed in monkey or mouse, exposed to reduced $\mathrm{pO}_{2}\left(8 \% \mathrm{O}_{2}\right)[10,39]$. Hypoxia induction of EPO in brain persists for up to $24 \mathrm{~h}$ or more [40]. In cultures of rat embryonic mesencephalic and adult subventricular zone precursor cells, EPO enhances proliferation and neuronal differentiation [41,42], providing further evidence for potential EPO activity in brain. Recently, comparisons of HIF- $1 \alpha$ with its isoform, HIF- $2 \alpha$ using siRNA technology suggest that HIF-2a, rather than HIF-1a, is the main regulator of EPO expression during hypoxia [43]. In astrocytes, for example, down regulation of HIF-2a but not HIF-1a drastically decreases EPO hypoxic expression [44]. Therapeutic activation of HIF is proposed as an alternate strategy to increase EPO production [45].

\section{EPO/EPO-R in CNS development}

\subsection{Endogenous EPO/EPO-R expression}

EPO and EPO-R are detected during development early before midgestation [7,8,46]. EPO and EPO-R is expressed in the central nervous system during human fetal development between 7 and 16 weeks, increases from 8 to 24 weeks [24]. EPO and EPO-R expression remain in human brain through adulthood [10]. EPO also persists in human cerebrospinal fluid after birth and is elevated by hypoxia [47]. In mice, EPO-R is expressed throughout the neural tube in the neuroepithelium by E8.5 and EPO expression follows by $0.5-1 \mathrm{~d}$, appearing to coincide with HIF-1 expression [8,25]. EPO-R expression in neural crest- and mesenchyme-derived cells around E10 is also followed by EPO expression one day later. The patterns of EPO-R and EPO expression are consistent with a paracrine and/or autocrine EPO response in developing brain.

\subsection{Deletion of EPO/EPO-R expression}

EPO and EPO-R null mice die around E13.5 due to lack of definitive erythropoiesis [5,6], and prior to death in utero, EPO and EPO-R null mice exhibit a thinning of the neuroepithelium and smaller brain size [7,25]. Mice that lack EPO or EPO-R exhibit incomplete closure of the neural tube at E10.5 when EPO-R is expressed at high levels in wild type mice. Neuronal cells harvested from EPO-R null mice at E10.5 prior to severe anemia in the embryo proper show intrinsic defects such as slower proliferation and increased sensitivity to hypoxic stress [7]. Incomplete closure of the neural tube is also characteristic of HIF-1 $\alpha-/-$ embryos that lack expression of the $\alpha$-subunit of HIF-1 [48]. EPO-R null mice can be rescued by an EPO-R transgene driven by the EPO-R promoter which restores full erythroid potential, normalizes brain development and rescues the increased apoptosis in the EPO-R null embryonic brain [15]. An EPO-R transgene driven by the promoter of the erythroid transcription factor, GATA-1, specifically compensates for EPO-R expression in erythroid cells and these animals survive through adulthood without gross morphologic abnormalities indicating that mice without EPO-R expression in brain are viable [16]. However, adult mice that lack EPO-R in the brain have significantly reduced neurogenesis in the subventricular zone and in a model for stroke have impaired migration of regenerating neurons to the peri-infarct cortex [8]. Coordinated expression of EPO and EPO-R in brain and the resultant brain defects due to lack of EPO/EPO-R suggests a role for EPO signaling during early brain development.

\section{EPO and the blood-brain barrier}

\subsection{EPO in human cerebrospinal fluid}

EPO with its molecular weight of $30.4 \mathrm{KD}$ is bigger than the molecular weight threshold for lipid-mediated transport across the blood-brain barrier. Whether EPO can cross the blood-brain barrier is an important question with implications for its use as a neuroprotective agent. Human brain autopsy suggests that EPO and EPO-R are up regulated after ischemic infarct or hypoxic damage [49]. EPO is increased in ventricular cerebrospinal fluid of patients with traumatic 
brain injury that does not correlate with serum EPO concentration, but does correlate with the degree of blood-brain-barrier dysfunction [50]. Analysis of patients with aneurismal subarachnoid hemorrhage showed elevated EPO concentrations in the cerebrospinal fluid with values above $1 \mathrm{mU} / \mathrm{ml}$ in 9 of 18 patients [51]. Elevated EPO in the cerebrospinal fluid did not correlate with serum levels or integrity of the blood-brain barrier, suggesting EPO synthesis in the central nervous system. In patients with traumatic brain injury, EPO was found in cerebrospinal fluid, and did not correlate with serum EPO, but did correlate with degree of blood-brain barrier dysfunction, further indicating that EPO does not cross the blood-brain barrier [50]. Analysis of blood and cerebrospinal fluid from neonates and children showed that while cerebrospinal fluid and plasma EPO were higher in asphyxiated infants, neonates with intraventricular hemorrhage had higher EPO in cerebrospinal fluid but not higher plasma EPO [47]. No correlation between cerebrospinal fluid and serum EPO levels were seen in infants treated with exogenous EPO [47].

\subsection{Systemic EPO administration in rodents}

The extent and manner in which systemic administration of exogenous EPO could cross the blood-brain barrier was examined specifically using labeled EPO. Intravenous administration of biotinylated-EPO provided evidence for biotin localization around capillaries in mouse brain $5 \mathrm{~h}$ after treatment that was eliminated by increase of unlabeled exogenous EPO, suggesting a specific receptor-mediated transport of EPO into the brain [52]. However, free biotin or other nuclear labels occurring from protein degradation complicate studies of EPO transport across the blood-brain barrier. EPO studies limited to $24 \mathrm{~h}$ were employed to avoid detection of radioactive degradation products and demonstrated that intravenous injection of radio labeled EPO crosses the intact blood-brain barrier at a very slow rate similar to albumin and was not saturable (characteristic of a receptor mediated transport system), suggesting extracellular pathways [53]. Brain uptake of EPO was 0.05 to $0.1 \%$ of the injected dose per gram of brain, peaking at $3 \mathrm{~h}$ after injection and was non-saturable. However, transit of EPO across the bloodbrain barrier may not pose a problem for EPO treatment of stroke or traumatic brain injury since cerebrovascular permeability to EPO and albumin is expected to increase with disruption of the blood-brain barrier. For example, in a rat stroke model, albumin extravasation was observed by $6 \mathrm{~h}$ and up to a 3.5 fold increase in albumin permeability within the first $24 \mathrm{~h}$ [54]. These data indicate that very low levels of EPO are able to cross the blood-brain barrier.

\subsection{Intravenous EPO administration in patients and non-human primates}

In patients given high doses of EPO intravenously, EPO increase in the cerebrospinal fluid was detected as early as $3 \mathrm{~h}$ after administration, followed first order kinetics, and depended on permeability of the blood-brain barrier, providing evidence that EPO transport proceeds via a first order transmembrane or non-receptor-mediated mechanism [55]. After single injection of a high level of EPO, cerebrospinal fluid of EPO reached levels up to $40 \mathrm{mIU} / \mathrm{ml}$ with a halflife similar to serum ( $26 \mathrm{~h}$ to $36 \mathrm{~h}$ ). Intravenous injection if In-111 labeled EPO in healthy and schizophrenic patients resulted in detection of significant radioactivity in brain that peaked at $4 \mathrm{~h}$ and persisted for two days [56]. In non-human primates, after intravenous injection, elevated EPO in spinal fluid was detected at $1 \mathrm{~h}$ and injection of very high EPO levels resulted in increased levels in spinal fluid expected to be neuroprotective by $2 \mathrm{~h}$ and peaking at $4 \mathrm{~h}$ [57]. Intraperitoneal injection resulted in a 10 fold lower EPO level, and there was no evidence of receptor mediated transport across the blood-brain barrier [57].

\subsection{EPO protection of the blood-brain barrier}

EPO has also been observed to provide direct protection of the blood-brain barrier. In rats, EPO pretreatment reduced the increase in blood-brain barrier permeability in pentylentetrazol induced seizures and reduced total seizure duration by 3.8 fold [58]. In an in vitro model of 
the bovine blood-brain barrier, EPO protected the blood-brain barrier against vascular endothelial growth factor (VEGF)-induced permeability [59]. In addition to its direct protective effect on neurons, protection of the blood-brain barrier may contribute indirectly to EPO neuroprotection.

\section{EPO stimulation of endothelial cells}

The endothelial response to EPO may contribute to the beneficial effects of EPO treatment in animal models of ischemic stroke $[60,61]$. EPO can promote endothelial cell proliferation and angiogenesis, migration and production of the vasodilator, nitric oxide (NO), and mobilize endothelial progenitor cells. EPO action on endothelial cells mediated by expression of the mature erythroid form of EPO-R increases proliferation and migration [1,2]. EPO upregulates matrix metalloproteinase 2 (MMP2) in endothelial cells promoting endothelial cell migration and demonstrates angiogenic response in vivo in the chick embryo chorioallantoic membrane $[62,63]$. EPO is produced in female reproductive organs in an estrogen and oxygen dependent manner and is indispensable for estrogen-dependent angiogenesis in mouse [64,65]. In endothelial cell culture EPO protects against anoxia-induced injury, Akt1 activation, maintenance of mitochondrial membrane potential, and inhibition of caspase 8-, 1- and 3-like activities [22]. Endothelial response to EPO is likely to participate in EPO neuroprotection.

\subsection{EPO mobilization of endothelial progenitor cells}

In humans, EPO treatment mobilized circulating endothelial progenitor cells in the peripheral blood in patients with ischemic heart disease and renal anemia as well as healthy subjects [66,67]. In mice, exogenous EPO mobilization of circulating endothelial progenitor cells promotes repair of injured endothelium with up regulation of EPO-R expression, phosphorylation of Akt and endothelial nitric oxide synthase (eNOS) and nitric oxide (NO) synthesis on circulating endothelial progenitor cells [66,68]. During exposure to chronic hypoxia, endogenous EPO promotes recruitment of circulating endothelial progenitor cells preventing pulmonary hypertension in wild type mice, but not in mice lacking EPO-R in nonerythroid lineages resulting in acceleration of pulmonary hypertension and vascular remodeling [17]. During embryogenesis, deletion of EPO or EPO-R in mice results in angiogenic defects at midgestation with decreased complexity of vessel networks 3 days prior to embryonic death due to severe anemia [69]. EPO stimulation of endothelial progenitor cells is an important component of EPO activity in vascular injury [68], and may contribute to EPO protection of in other non-hematopoietic organ systems including the ischemic brain.

\subsection{EPO and nitric oxide production}

EPO has the potential to modulate oxygen delivery through regulation of endothelial NO production. In endothelial cell cultures, although short term exposure to EPO decreases or leaves unchanged eNOS and endothelin-1 expression [70,71], the combination of EPO and hypoxia increases EPO-R and eNOS expression, and nitric oxide (NO) and cGMP production, demonstrating a direct effect of EPO on endothelial eNOS and NO production [72]. In transgenic mice expressing high levels of EPO, the high red cell production is accompanied by increased endothelial nitric oxide synthase (eNOS), NO production and NO relaxation, offsetting the adverse effect of elevated hematocrit (up to 80\%) [73]. These mice with high hematocrit also exhibit elevated endothelin-1 expression that accounts for increased mortality during acute exposure to L-NAME, an inhibitor of NO synthase [74]. EPO administration for 14 days in healthy rats increased hematocrit as well as eNOS expression and augmented NOdependent vasodilatation [75]. In contrast, in chronic lung disease, endothelium-dependent vasodilatation in response to acetylcholine is inhibited in patients with polycythemia with high hematocrit who may have very low EPO levels, and this inhibition can be reversed by normalization of blood hemoglobin concentration, suggesting that in the absence of high 
elevation of EPO levels, increased hemoglobin decreases NO bioavailability [76]. Adenoviral vector encoding EPO injected into brain in rabbits stimulated endothelial nitric oxide synthase expression and NO production, increased cGMP in transduced arteries, augmented endothelium-dependent relaxation to acetylcholine and attenuated contractile response to histamine by $48 \mathrm{~h}$ after injection without affecting red blood cell count [77]. The participation of EPO in regulation of NO production and blood flow may contribute to its neuroprotective role in brain ischemia. Note, however, that EPO effect on nitric oxide synthase and NO production may depend on cell type or conditions. EPO inhibits expression of inducible nitric oxide synthase (iNOS) in the hippocampus after bilateral carotid occlusion and reperfusion in the gerbil [78] and in primary oligodendrocyte cultures exposed to inflammatory stimuli [79].

\subsection{EPO production and endothelial cells}

EPO production in brain has also been attributed to endothelial cells. Following ischemic stroke in mice, basal EPO expression in neurons and astrocytes is accompanied by post ischemic EPO expression localizing to endothelial cells 1 day after stroke [11]. In human brain, EPO immunoreactivity appeared in vascular endothelium of fresh infarcts that was associated with acute hypoxic brain damage [49]. Whether EPO production in endothelial cells is sufficient to affect a paracrine EPO response in neural cells has yet to be determined.

\section{EPO and neuroprotection in animal models}

\subsection{EPO and ischemic preconditioning}

Prior exposure to sublethal ischemia or hypoxia can provide tolerance to cerebral ischemia or preconditioning. For example, mice exposed to sublethal low levels of oxygen tension $24 \mathrm{~h}$ prior to focal permanent ischemia in mice resulted in a reduction in infarct volumes [80]. Preconditioning was associated with cerebral expression of HIF- $1 \alpha$ and HIF-1 target genes such as EPO and VEGF. The importance of endogenous EPO in hypoxia preconditioning for cerebral infarct in mice was demonstrated by administration of soluble EPO-R in the cerebral ventricle that reduced the protective effect in the rage of 40\%-88\% [39,81]. In an in vitro model of cerebral ischemia, EPO mediated ischemic tolerance in primary cortical neurons, and soluble EPO-R, anti-EPO-R antibody and a JAK2 inhibitor blocked protection [82]. In the retina, hypoxic preconditioning protects against light-induced apoptosis and interferes with caspase-1 activation, and this activity could be mimicked by EPO injected intraperitoneally to provide neuroprotection to retinal photoreceptors [83]. High levels of transgenic EPO expression in the retina also protected against light-induced degeneration of photoreceptors but not in genetic models of retinal degeneration [84].

\subsection{Increasing brain EPO}

The neurotrophic effects of EPO demonstrated by in vitro neural cell cultures and by defects associated with deletion of EPO/EPO-R expression in brain suggest possible EPO protective action before, during or after neuronal injury. Studies in animal models show the potential for EPO neuroprotection in brain ischemia or trauma. Evidence that endogenous EPO may provide neuroprotection was first demonstrated in gerbils with mild brain ischemic treatment after infusion into the lateral ventricle of soluble EPO-R capable of binding EPO resulting in neuronal degeneration and impaired learning ability [85]. Infusion of exogenous EPO was neuroprotective against ischemic damage of hippocampal CA1 neurons and ischemia-induced learning disability. In mice after cerebral infarct induced by focal permanent ischemia, induction of EPO-R in brain is observed in endothelial cells, microglia and astrocytes in a temporal manner followed by induction of EPO expression [11]. Intracerebral injection of exogenous $\mathrm{EPO} 24 \mathrm{~h}$ prior to challenge reduces infarct volume by about $50 \%$. In rats, permanent ischemia of the left cortex resulted in up regulation of EPO-R expression in the periphery or ischemic penumbra [86]. Infusion of EPO into the cerebroventricle just after middle cerebral 
artery occlusion was neuroprotective, reduced secondary thalamic degeneration and reduced ischemia-induced place navigation disability. Induction of EPO-R is also observed in cerebral ischemia in the neonatal rat brain in ischemic areas [87]. These studies provide evidence for increase of EPO-R after infarct to facilitate EPO signaling and provide protection to minimize the damage or damaged area, and that administration of exogenous EPO directly to brain significantly reduces damage and infarct size in rodent models. As a potential treatment in neurodegenerative disease, in a mouse model of Parkinsonism induced by drug treatment, exogenous EPO injected above the substantia nigra improved locomotor activity and survival of dopaminergic neurons [88]. These animal models suggest the potential for direct administration of EPO in brain for treatment of brain ischemia/trauma or disease.

\subsection{Intravenous/intraperitoneal EPO administration}

The size of EPO limits its ability to cross the blood-brain barrier [53]. However, in neonatal or adult rats after focal brain ischemia, brain trauma or experimental autoimmune encephalomyelitis systemic or intraperitoneal administration of exogenous EPO is neuroprotective $[52,89,90]$. Intravenously administered EPO also provides protection in animal models for spinal cord injury with improved functional neurological status [91,92]. The neuroprotective effects of systemic or intraperitoneal EPO administration suggest that sufficient amounts of exogenous EPO cross the blood-brain barrier to provide a direct neuroprotective effect, or that exogenous EPO acts on the other side of the blood-brain barrier and provides neuroprotection via an indirect mechanism. For example, in focal ischemia in rats, exogenous EPO administered intraperitoneally reduces astrocyte activation, recruitment of leukocytes and microglia to the infarct area and reduces proinflammatory cytokine production by more 50\% [93]. EPO-increased vascular endothelial growth factor and brainderived neurotrophic factor (BDNF) observed in rats treated with exogenous EPO $24 \mathrm{~h}$ after embolic stroke may be the direct contributors to angiogenesis and neurogenesis associated with brain repair [60]. In cultures of rat hippocampal neurons, EPO can directly increase BDNF expression [94]. Increase in EPO bioavailability by over expression in brain or by intravenous injection can also modulate ventilatory response to hypoxia [95]. In experimental subarachnoid hemorrhage in rats, subcutaneously administered EPO provided protection preserving cerebral blood flow autoregulation [96]. Modeling other neurodegenerative disorders, intraperitoneal EPO administration enhances cognitive functioning in a conditioned taste aversion mouse model that may relate to schizophrenia [56]. Whether or not EPO crosses the blood-brain barrier, systemic EPO administration is protective in these animal models of brain ischemia/ trauma or disease.

\subsection{EPO and oligodendrocytes}

EPO may play a role in activation of oligodendrocyte progenitors or protection of oligodendrocytes. EPO and EPO-R are expressed in oligodendrocytes and EPO promotes oligodendrocyte differentiation/maturation in culture [97]. EPO exhibits antineuroinflammatory activity in experimental autoimmune encephalomyelitis in mice improving neurological functional recovery and increasing oligodendrocyte progenitor cell proliferation, and, in culture, EPO has been shown to protect oligodendrocytes from interferon- $\gamma$ and lipopolysaccharide cytotoxicity specifically inducible nitric oxide synthase (iNOS) expression and nitrite production $[79,98,99]$. In the rat model for spinal cord in jury EPO treatment reduces apoptotic oligodendrocytes and promotes preservation of white matter [100,101]. Protection of oligodendrocytes has implications for neurological disorders such as for multiple sclerosis and spinal cord injury. 


\section{EPO neuroprotection and endothelium}

Endothelial cells are an important component to the neural stem cell niche [102], raising the possibility that EPO stimulation of endothelium may contribute directly to neurogenesis and/ or neuroprotection. Rats treated with EPO (intraperitoneally) at 24 hours following ischemic stroke exhibited increased VEGF and BDNF levels in brain as well as angiogenesis and neurogenesis $[60,61]$. EPO enhanced angiogenesis around the ischemic boundary region and induced neuroblast migration toward this region, suggesting a link between these two processes [61]. In co-culture, EPO promoted mouse brain endothelial cell-coupled migration of neural progenitor cells from adult subventricular zone and up regulation in endothelial cells of MMP2 and MMP9 secretion that directly increases neural progenitor cell migration, but EPO activated endothelial cells did not increase neural progenitor cell differentiation. Endothelial response is likely an important contributor to EPO neuroprotection in vivo (Figure 2). Conversely, endothelial response to elevated EPO levels or to the resultant high hematocrit might be deleterious and contribute to deteriorating outcome after stroke should NO production reach toxic levels or exacerbate formation of free radicals and/or endothelial activation [103,104].

\section{EPO as potential treatment in human brain disease}

A pilot proof-of-concept clinical study of EPO treatment for ischemic stroke confirmed by MRI indicated a trend for reduction in infarct size and improvement in follow-up and outcome scales in patients treated within $8 \mathrm{~h}$ of clinical symptoms [105]. With intravenous treatment during the first three days after stroke, EPO in the cerebrospinal fluid increased almost two orders of magnitude greater than untreated patients. Larger trials are warranted to validate the therapeutic potential of EPO in brain disease [106].

\section{Modified EPO/EPO-R}

EPO administration can give rise to high hematocrit that increases blood viscosity, which can compromise the endothelial and neuroprotective activity associated with EPO. For example, endothelial response to excessive oxygen supply via increased hematocrit and NO-mediated vasodilation might lead to elevated ROS (reactive oxygen species) production and be deleterious [103,104]. Adverse events associated with EPO treatment include hypertension and increase in inflammatory markers and thrombosis. Rats with partial nephrectomy treated with EPO exhibited a rise in blood pressure even without the correction of anemia (achieved by an iron deficient diet) [107]. Transgenic mice expressing high levels of EPO with high hematocrit exhibit no change in cerebral blood flow but reduced brain vessel density and increased vessel diameter, no significant increase in vascular permeability although apparent vascular endothelial cell activation, and following permanent middle cerebral artery occlusion (MCAO), a 49\% increase in infarct volume [103,104]. Several strategies have been proposed in efforts to separate the neuroprotective effects from the erythropoietic effects of EPO.

\subsection{Asialoerythropoietin}

Glycosylation of EPO is necessary for stability in the circulation and asialoerythropoietin is rapidly cleared from blood, although in vitro asialoerythropoietin has a higher specific activity and binds faster to hematopoietic cells [108-110]. Asialoerythropoietin exhibited neuroprotection in rodent models for focal ischemia and hypoxia in brain and spinal cord compression when administered intravenously at the time of challenge or $24 \mathrm{~h}$ before [111-113]. Therefore, because of its rapid clearance from the circulation, asialoerythropoietin administration in rodents is able to uncouple stimulation of erythropoiesis from the neuroprotective effects associated with EPO. 


\subsection{Carbamylated EPO}

Carbamylation of the lysines in EPO interferes with binding to EPO-R on hematopoietic cells, did not increase hematocrit even after 8 weeks of administration in rats, but bound to neural cells, protected them from apoptosis and exhibited comparable neuroprotective activity as EPO in focal ischemia in rats [114]. While both carbamylated EPO and asialoerythropoietin provide neuroprotection in vivo in animal models without stimulation of erythropoiesis,

asialoerythropoietin is able to bind to the mature erythroid form of EPO-R while carbamylated EPO does not, suggesting that carbamylated EPO might be binding to an alternate receptor or heteromeric receptor complex.

\subsection{An alternate EPO receptor?}

In hematopoietic cell lines, EPO stimulated a transient phosphorylation of the common betachain (human CD131) shared by receptors for GM-CSF, IL-3 and IL-5, and a direct interaction between EPO-R and the common beta-chain was observed in cells overexpressing EPO-R $[115,116]$. Mice that lack the common beta-chain exhibit normal EPO response in hematopoietic cells indicating that the common beta-chain does not participate in erythropoiesis [117]. However, in a spinal cord compression model with intraperitoneally administered EPO, common beta chain null mice do not exhibit the accelerated recovery with EPO or carbamylated compared with wild type mice treated with carbamylated EPO [118]. A heterocomplex between the common beta chain and EPO-R has been proposed as a nonhematopoietic receptor mediating EPO protection [119]. The cell specificity and the molecular structure and/or interactions between carbamylated EPO and its receptor and the molecular interactions between the common beta chain and EPO-R and their functional specificity have yet to be determined.

\section{Conclusion}

EPO increases red cell mass resulting in elevated oxygen delivery, Rather than being specific for erythroid cell differentiation, EPO may act more generally as a survival factor for select progenitor cells and neurons. EPO activity appears to be optimum with up regulation of EPO$\mathrm{R}$ and increased bioavailability of EPO in the local environment. In brain EPO has the potential to provide neuroprotection indirectly via regulation of the red cell mass and/or stimulation of endothelium, or directly in maintenance of neurogenesis or survival of neurons undergoing stress/ischemic challenge (Figure 3). The well-known hypoxia induction of circulating EPO and its required role in production of mature red blood cells results in possible neuroprotective activity through regulation of oxygen delivery to the tissues including brain. EPO can also elevate blood oxygenation indirectly via increase ventilation. EPO effect on endothelium can also contribute to EPO neuroprotection as endothelial response to EPO can modify production of factors that regulate blood flow, endothelial cell survival, endothelial progenitor cell mobilization and angiogenesis, and secretion of factors that affect neurogenesis and neuroblast migration. EPO production in neural cells can increase the local bioavailability of EPO independent of transit through the blood-brain barrier to promote neuronal cell survival, neurogenesis and migration of regenerating neurons. These activities of EPO in cell culture and in animal models provide evidence for endogenous EPO production as a neuroprotective agent for tissue maintenance, and suggest its potential as a therapeutic cytokine for brain trauma, ischemic challenge or neurodegenerative disease.

\section{Biography}

Constance Tom Noguchi, Ph.D. is Chief of the Molecular Cell Biology Section in the Molecular Medicine Branch at the National Institute of Diabetes and Digestive and Kidney Diseases at 
the National Institutes of Health in Bethesda, Maryland, U.S.A. She obtained her Ph.D. in Physics from the George Washington University, Washington, D.C.

\section{Abbreviations}

EPO, erythropoietin; EPO-R, erythropoietin receptor; VEGF, vascular endothelial growth factor; BDNF, brain derived neurotrophic factor; NO, nitric oxide; NPC, neural progenitor cell; MMP, matrix metalloproteinase.

\section{References}

1. Anagnostou A, Liu Z, Steiner M, et al. Erythropoietin receptor mRNA expression in human endothelial cells. Proc Natl Acad Sci U S A 1994;91(9):3974-8. [PubMed: 8171022]

2. Anagnostou A, Lee ES, Kessimian N, Levinson R, Steiner M. Erythropoietin has a mitogenic and positive chemotactic effect on endothelial cells. Proc Natl Acad Sci U S A 1990;87(15):5978-82. [PubMed: 2165612]

3. Morishita E, Masuda S, Nagao M, Yasuda Y, Sasaki R. Erythropoietin receptor is expressed in rat hippocampal and cerebral cortical neurons, and erythropoietin prevents in vitro glutamate-induced neuronal death. Neuroscience 1997;76(1):105-16. [PubMed: 8971763]

4. Jelkmann W, Wagner K. Beneficial and ominous aspects of the pleiotropic action of erythropoietin. Ann Hematol 2004;83(11):673-86. [PubMed: 15322761]

5. Wu H, Liu X, Jaenisch R, Lodish HF. Generation of committed erythroid BFU-E and CFU-E progenitors does not require erythropoietin or the erythropoietin receptor. Cell 1995;83(1):59-67. [PubMed: 7553874]

6. Lin CS, Lim SK, D'Agati V, Costantini F. Differential effects of an erythropoietin receptor gene disruption on primitive and definitive erythropoiesis. Genes Dev 1996;10(2):154-64. [PubMed: 8566749]

7. Yu X, Shacka JJ, Eells JB, et al. Erythropoietin receptor signalling is required for normal brain development. Development 2002;129(2):505-16. [PubMed: 11807041]

8. Tsai PT, Ohab JJ, Kertesz N, et al. A critical role of erythropoietin receptor in neurogenesis and poststroke recovery. J Neurosci 2006;26(4):1269-74. [PubMed: 16436614]

9. Masuda S, Okano M, Yamagishi K, Nagao M, Ueda M, Sasaki R. A novel site of erythropoietin production. Oxygen-dependent production in cultured rat astrocytes. J Biol Chem 1994;269(30): 19488-93. [PubMed: 8034718]

10. Marti HH, Wenger RH, Rivas LA, et al. Erythropoietin gene expression in human, monkey and murine brain. Eur J Neurosci 1996;8(4):666-76. [PubMed: 9081618]

11. Bernaudin M, Marti HH, Roussel S, et al. A potential role for erythropoietin in focal permanent cerebral ischemia in mice. J Cereb Blood Flow Metab 1999;19(6):643-51. [PubMed: 10366194]

12. Marti HH. Erythropoietin and the hypoxic brain. J Exp Biol 2004;207(Pt 18):3233-42. [PubMed: 15299044]

13. Ogilvie M, Yu X, Nicolas-Metral V, et al. Erythropoietin stimulates proliferation and interferes with differentiation of myoblasts. J Biol Chem 2000;275(50):39754-61. [PubMed: 10995753]

14. Shingo T, Sorokan ST, Shimazaki T, Weiss S. Erythropoietin regulates the in vitro and in vivo production of neuronal progenitors by mammalian forebrain neural stem cells. J Neurosci 2001;21 (24):9733-43. [PubMed: 11739582]

15. Yu X, Lin CS, Costantini F, Noguchi CT. The human erythropoietin receptor gene rescues erythropoiesis and developmental defects in the erythropoietin receptor null mouse. Blood 2001;98 (2):475-7. [PubMed: 11435319]

16. Suzuki N, Ohneda O, Takahashi S, et al. Erythroid-specific expression of the erythropoietin receptor rescued its null mutant mice from lethality. Blood 2002;100(7):2279-88. [PubMed: 12239135]

17. Satoh K, Kagaya Y, Nakano M, et al. Important role of endogenous erythropoietin system in recruitment of endothelial progenitor cells in hypoxia-induced pulmonary hypertension in mice. Circulation 2006;113(11):1442-50. [PubMed: 16534010] 
18. Jelkmann W. Effects of erythropoietin on brain function. Curr Pharm Biotechnol 2005;6(1):65-79. [PubMed: 15727557]

19. Quelle FW, Wang D, Nosaka T, et al. Erythropoietin induces activation of Stat5 through association with specific tyrosines on the receptor that are not required for a mitogenic response. Mol Cell Biol 1996;16(4):1622-31. [PubMed: 8657137]

20. Zhao W, Kitidis C, Fleming MD, Lodish HF, Ghaffari S. Erythropoietin stimulates phosphorylation and activation of GATA-1 via the PI3-kinase/AKT signaling pathway. Blood 2006;107(3):907-15. [PubMed: 16204311]

21. Digicaylioglu M, Lipton SA. Erythropoietin-mediated neuroprotection involves cross-talk between Jak2 and NF-kappaB signalling cascades. Nature 2001;412(6847):641-7. [PubMed: 11493922]

22. Chong ZZ, Kang JQ, Maiese K. Erythropoietin is a novel vascular protectant through activation of Akt1 and mitochondrial modulation of cysteine proteases. Circulation 2002;106(23):2973-9. [PubMed: 12460881]

23. Liu C, Shen K, Liu Z, Noguchi CT. Regulated human erythropoietin receptor expression in mouse brain. J Biol Chem 1997;272(51):32395-400. [PubMed: 9405448]

24. Juul SE, Anderson DK, Li Y, Christensen RD. Erythropoietin and erythropoietin receptor in the developing human central nervous system. Pediatr Res 1998;43(1):40-9. [PubMed: 9432111]

25. Knabe W, Knerlich F, Washausen S, et al. Expression patterns of erythropoietin and its receptor in the developing midbrain. Anat Embryol (Berl) 2004;207(6):503-12. [PubMed: 14770308]

26. David RB, Lim GB, Moritz KM, Koukoulas I, Wintour EM. Quantitation of the mRNA levels of Epo and EpoR in various tissues in the ovine fetus. Mol Cell Endocrinol 2002;188(12):207-18. [PubMed: 11911958]

27. Digicaylioglu M, Bichet S, Marti HH, et al. Localization of specific erythropoietin binding sites in defined areas of the mouse brain. Proc Natl Acad Sci U S A 1995;92(9):3717-20. [PubMed: 7731971]

28. Chin K, Yu X, Beleslin-Cokic B, et al. Production and processing of erythropoietin receptor transcripts in brain. Brain Res Mol Brain Res 2000;81(12):29-42. [PubMed: 11000476]

29. Lewczuk P, Hasselblatt M, Kamrowski-Kruck H, et al. Survival of hippocampal neurons in culture upon hypoxia: effect of erythropoietin. Neuroreport 2000;11(16):3485-8. [PubMed: 11095504]

30. Nagai A, Nakagawa E, Choi HB, Hatori K, Kobayashi S, Kim SU. Erythropoietin and erythropoietin receptors in human CNS neurons, astrocytes, microglia, and oligodendrocytes grown in culture. J Neuropathol Exp Neurol 2001;60(4):386-92. [PubMed: 11305874]

31. Chin K, Oda N, Shen K, Noguchi CT. Regulation of transcription of the human erythropoietin receptor gene by proteins binding to GATA-1 and Sp1 motifs. Nucleic Acids Res 1995;23(15):3041-9. [PubMed: 7659529]

32. Pandolfi PP, Roth ME, Karis A, et al. Targeted disruption of the GATA3 gene causes severe abnormalities in the nervous system and in fetal liver haematopoiesis. Nat Genet 1995;11(1):40-4. [PubMed: 7550312]

33. Yamaji R, Okada T, Moriya M, et al. Brain capillary endothelial cells express two forms of erythropoietin receptor mRNA. Eur J Biochem 1996;239(2):494-500. [PubMed: 8706759]

34. Livnah O, Stura EA, Middleton SA, Johnson DL, Jolliffe LK, Wilson IA. Crystallographic evidence for preformed dimers of erythropoietin receptor before ligand activation. Science 1999;283(5404): 987-90. [PubMed: 9974392]

35. Kilic E, Kilic U, Soliz J, Bassetti CL, Gassmann M, Hermann DM. Brain-derived erythropoietin protects from focal cerebral ischemia by dual activation of ERK-1/-2 and Akt pathways. Faseb J 2005;19(14):2026-8. [PubMed: 16207820]

36. Chong ZZ, Kang JQ, Maiese K. Erythropoietin fosters both intrinsic and extrinsic neuronal protection through modulation of microglia, Akt1, Bad, and caspase-mediated pathways. Br J Pharmacol 2003;138(6):1107-18. [PubMed: 12684267]

37. Um M, Lodish HF. Antiapoptotic effects of erythropoietin in differentiated neuroblastoma SH-SY5Y cells require activation of both the STAT5 and AKT signaling pathways. J Biol Chem 2006;281(9): 5648-56. [PubMed: 16407271]

38. Bunn HF, Gu J, Huang LE, Park JW, Zhu H. Erythropoietin: a model system for studying oxygendependent gene regulation. J Exp Biol 1998;201(Pt 8):1197-201. [PubMed: 9510530] 
39. Prass K, Scharff A, Ruscher K, et al. Hypoxia-induced stroke tolerance in the mouse is mediated by erythropoietin. Stroke 2003;34(8):1981-6. [PubMed: 12829864]

40. Chikuma M, Masuda S, Kobayashi T, Nagao M, Sasaki R. Tissue-specific regulation of erythropoietin production in the murine kidney, brain, and uterus. Am J Physiol Endocrinol Metab 2000;279 (6):E1242-8. [PubMed: 11093910]

41. Studer L, Csete M, Lee SH, et al. Enhanced proliferation, survival, and dopaminergic differentiation of CNS precursors in lowered oxygen. J Neurosci 2000;20(19):7377-83. [PubMed: 11007896]

42. Wang L, Zhang ZG, Zhang RL, et al. Neurogenin 1 mediates erythropoietin enhanced differentiation of adult neural progenitor cells. J Cereb Blood Flow Metab 2006;26(4):556-64. [PubMed: 16136056]

43. Warnecke C, Zaborowska Z, Kurreck J, et al. Differentiating the functional role of hypoxia-inducible factor (HIF)-1alpha and HIF-2alpha (EPAS-1) by the use of RNA interference: erythropoietin is a HIF-2alpha target gene in Hep3B and Kelly cells. Faseb J 2004;18(12):1462-4. [PubMed: 15240563]

44. Chavez JC, Baranova O, Lin J, Pichiule P. The transcriptional activator hypoxia inducible factor 2 (HIF-2/EPAS-1) regulates the oxygen-dependent expression of erythropoietin in cortical astrocytes. J Neurosci 2006;26(37):9471-81. [PubMed: 16971531]

45. Bunn HF. New agents that stimulate erythropoiesis. Blood. 2006

46. Juul S. Erythropoietin in the central nervous system, and its use to prevent hypoxicischemic brain damage. Acta Paediatr Suppl 2002;91(438):36-42. [PubMed: 12477263]

47. Juul SE, Stallings SA, Christensen RD. Erythropoietin in the cerebrospinal fluid of neonates who sustained CNS injury. Pediatr Res 1999;46(5):543-7. [PubMed: 10541316]

48. Iyer NV, Kotch LE, Agani F, et al. Cellular and developmental control of O2 homeostasis by hypoxiainducible factor 1 alpha. Genes Dev 1998;12(2):149-62. [PubMed: 9436976]

49. Siren AL, Knerlich F, Poser W, Gleiter CH, Bruck W, Ehrenreich H. Erythropoietin and erythropoietin receptor in human ischemic/hypoxic brain. Acta Neuropathol (Berl) 2001;101(3):271-6. [PubMed: 11307627]

50. Marti HH, Gassmann M, Wenger RH, et al. Detection of erythropoietin in human liquor: intrinsic erythropoietin production in the brain. Kidney Int 1997;51(2):416-8. [PubMed: 9027715]

51. Springborg JB, Sonne B, Frederiksen HJ, et al. Erythropoietin in the cerebrospinal fluid of patients with aneurysmal subarachnoid haemorrhage originates from the brain. Brain Res 2003;984(12):1438. [PubMed: 12932848]

52. Brines ML, Ghezzi P, Keenan S, et al. Erythropoietin crosses the blood-brain barrier to protect against experimental brain injury. Proc Natl Acad Sci U S A 2000;97(19):10526-31. [PubMed: 10984541]

53. Banks WA, Jumbe NL, Farrell CL, Niehoff ML. Heatherington AC. Passage of erythropoietic agents across the blood-brain barrier: a comparison of human and murine erythropoietin and the analog darbepoetin alfa. Eur J Pharmacol 2004;505(13):93-101. [PubMed: 15556141]

54. Abraham CS, Harada N, Deli MA, Niwa M. Transient forebrain ischemia increases the blood-brain barrier permeability for albumin in stroke-prone spontaneously hypertensive rats. Cell Mol Neurobiol 2002;22(4):455-62. [PubMed: 12507394]

55. Xenocostas A, Cheung WK, Farrell F, et al. The pharmacokinetics of erythropoietin in the cerebrospinal fluid after intravenous administration of recombinant human erythropoietin. Eur J Clin Pharmacol 2005;61(3):189-95. [PubMed: 15776276]

56. Ehrenreich H, Degner D, Meller J, et al. Erythropoietin: a candidate compound for neuroprotection in schizophrenia. Mol Psychiatry 2004;9(1):42-54. [PubMed: 14581931]

57. Juul SE, McPherson RJ, Farrell FX, Jolliffe L, Ness DJ, Gleason CA. Erytropoietin concentrations in cerebrospinal fluid of nonhuman primates and fetal sheep following high-dose recombinant erythropoietin. Biol Neonate 2004;85(2):138-44. [PubMed: 14639039]

58. Uzum G, Sarper Diler A, Bahcekapili N, Ziya Ziylan Y. Erythropoietin prevents the increase in bloodbrain barrier permeability during pentylentetrazol induced seizures. Life Sci 2006;78(22):2571-6. [PubMed: 16343549]

59. Martinez-Estrada OM, Rodriguez-Millan E, Gonzalez-De Vicente E, Reina M, Vilaro S, Fabre M. Erythropoietin protects the in vitro blood-brain barrier against VEGF-induced permeability. Eur J Neurosci 2003;18(9):2538-44. [PubMed: 14622154] 
60. Wang L, Zhang Z, Wang Y, Zhang R, Chopp M. Treatment of stroke with erythropoietin enhances neurogenesis and angiogenesis and improves neurological function in rats. Stroke 2004;35(7):17327. [PubMed: 15178821]

61. Wang L, Zhang ZG, Zhang RL, et al. Matrix metalloproteinase 2 (MMP2) and MMP9 secreted by erythropoietin-activated endothelial cells promote neural progenitor cell migration. J Neurosci 2006;26(22):5996-6003. [PubMed: 16738242]

62. Ribatti D, Presta M, Vacca A, et al. Human erythropoietin induces a pro-angiogenic phenotype in cultured endothelial cells and stimulates neovascularization in vivo. Blood 1999;93(8):2627-36. [PubMed: 10194442]

63. Ribatti D, Vacca A, Roccaro AM, Crivellato E, Presta M. Erythropoietin as an angiogenic factor. Eur J Clin Invest 2003;33(10):891-6. [PubMed: 14511361]

64. Yasuda Y, Masuda S, Chikuma M, Inoue K, Nagao M, Sasaki R. Estrogen-dependent production of erythropoietin in uterus and its implication in uterine angiogenesis. J Biol Chem 1998;273(39): 25381-7. [PubMed: 9738005]

65. Masuda S, Kobayashi T, Chikuma M, Nagao M, Sasaki R. The oviduct produces erythropoietin in an estrogen- and oxygen-dependent manner. Am J Physiol Endocrinol Metab 2000;278(6):E103844. [PubMed: 10827006]

66. Heeschen C, Aicher A, Lehmann R, et al. Erythropoietin is a potent physiologic stimulus for endothelial progenitor cell mobilization. Blood 2003;102(4):1340-6. [PubMed: 12702503]

67. Bahlmann FH, De Groot K, Spandau JM, et al. Erythropoietin regulates endothelial progenitor cells. Blood 2004;103(3):921-6. [PubMed: 14525788]

68. Urao N, Okigaki M, Yamada H, et al. Erythropoietin-mobilized endothelial progenitors enhance reendothelialization via Akt-endothelial nitric oxide synthase activation and prevent neointimal hyperplasia. Circ Res 2006;98(11):1405-13. [PubMed: 16645141]

69. Kertesz N, Wu J, Chen TH, Sucov HM, Wu H. The role of erythropoietin in regulating angiogenesis. Dev Biol 2004;276(1):101-10. [PubMed: 15531367]

70. Wang XQ, Vaziri ND. Erythropoietin depresses nitric oxide synthase expression by human endothelial cells. Hypertension 1999;33(3):894-9. [PubMed: 10082505]

71. Banerjee D, Rodriguez M, Nag M, Adamson JW. Exposure of endothelial cells to recombinant human erythropoietin induces nitric oxide synthase activity. Kidney Int 2000;57(5):1895-904. [PubMed: 10792608]

72. Beleslin-Cokic BB, Cokic VP, Yu X, Weksler BB, Schechter AN, Noguchi CT. Erythropoietin and hypoxia stimulate erythropoietin receptor and nitric oxide production by endothelial cells. Blood 2004;104(7):2073-80. [PubMed: 15205261]

73. Ruschitzka FT, Wenger RH, Stallmach T, et al. Nitric oxide prevents cardiovascular disease and determines survival in polyglobulic mice overexpressing erythropoietin. Proc Natl Acad Sci U S A 2000;97(21):11609-13. [PubMed: 11027359]

74. Quaschning T, Ruschitzka F, Stallmach T, et al. Erythropoietin-induced excessive erythrocytosis activates the tissue endothelin system in mice. Faseb J 2003;17(2):259-61. [PubMed: 12490547]

75. Kanagy NL, Perrine MF, Cheung DK, Walker BR. Erythropoietin administration in vivo increases vascular nitric oxide synthase expression. J Cardiovasc Pharmacol 2003;42(4):527-33. [PubMed: 14508239]

76. Defouilloy C, Teiger E, Sediame S, et al. Polycythemia impairs vasodilator response to acetylcholine in patients with chronic hypoxemic lung disease. Am J Respir Crit Care Med 1998;157(5 Pt 1):145260. [PubMed: 9603123]

77. Santhanam AV, Smith LA, Nath KA, Katusic ZS. In vivo stimulatory effect of erythropoietin on endothelial nitric oxide synthase in cerebral arteries. Am J Physiol Heart Circ Physiol 2006;291 (2):H781-6. [PubMed: 16565320]

78. Calapai G, Marciano MC, Corica F, et al. Erythropoietin protects against brain ischemic injury by inhibition of nitric oxide formation. Eur J Pharmacol 2000;401(3):349-56. [PubMed: 10936493]

79. Genc K, Genc S, Baskin H, Semin I. Erythropoietin decreases cytotoxicity and nitric oxide formation induced by inflammatory stimuli in rat oligodendrocytes. Physiol Res 2006;55(1):33-8. [PubMed: 15857166] 
80. Bernaudin M, Nedelec AS, Divoux D, MacKenzie ET, Petit E, Schumann-Bard P. Normobaric hypoxia induces tolerance to focal permanent cerebral ischemia in association with an increased expression of hypoxia-inducible factor-1 and its target genes, erythropoietin and VEGF, in the adult mouse brain. J Cereb Blood Flow Metab 2002;22(4):393-403. [PubMed: 11919510]

81. Malhotra S, Savitz SI, Ocava L, Rosenbaum DM. Ischemic preconditioning is mediated by erythropoietin through PI-3 kinase signaling in an animal model of transient ischemic attack. J Neurosci Res 2006;83(1):19-27. [PubMed: 16307446]

82. Ruscher K, Freyer D, Karsch M, et al. Erythropoietin is a paracrine mediator of ischemic tolerance in the brain: evidence from an in vitro model. J Neurosci 2002;22(23):10291-301. [PubMed: 12451129]

83. Grimm C, Wenzel A, Groszer M, et al. HIF-1-induced erythropoietin in the hypoxic retina protects against light-induced retinal degeneration. Nat Med 2002;8(7):718-24. [PubMed: 12068288]

84. Grimm C, Wenzel A, Stanescu D, et al. Constitutive overexpression of human erythropoietin protects the mouse retina against induced but not inherited retinal degeneration. J Neurosci 2004;24(25): 5651-8. [PubMed: 15215287]

85. Sakanaka M, Wen TC, Matsuda S, et al. In vivo evidence that erythropoietin protects neurons from ischemic damage. Proc Natl Acad Sci U S A 1998;95(8):4635-40. [PubMed: 9539790]

86. Sadamoto Y, Igase K, Sakanaka M, et al. Erythropoietin prevents place navigation disability and cortical infarction in rats with permanent occlusion of the middle cerebral artery. Biochem Biophys Res Commun 1998;253(1):26-32. [PubMed: 9875214]

87. Wen TC, Rogido M, Genetta T, Sola AE. Permanent focal cerebral ischemia activates erythropoietin receptor in the neonatal rat brain. Neurosci Lett 2004;355(3):165-8. [PubMed: 14732457]

88. Genc S, Kuralay F, Genc K, et al. Erythropoietin exerts neuroprotection in 1-methyl-4-phenyl-1,2,3,6tetrahydropyridine-treated C57/BL mice via increasing nitric oxide production. Neurosci Lett 2001;298(2):139-41. [PubMed: 11163297]

89. Sun Y, Zhou C, Polk P, Nanda A, Zhang JH. Mechanisms of erythropoietin-induced brain protection in neonatal hypoxia-ischemia rat model. J Cereb Blood Flow Metab 2004;24(2):259-70. [PubMed: 14747752]

90. Yatsiv I, Grigoriadis N, Simeonidou C, et al. Erythropoietin is neuroprotective, improves functional recovery, and reduces neuronal apoptosis and inflammation in a rodent model of experimental closed head injury. Faseb J 2005;19(12):1701-3. [PubMed: 16099948]

91. Celik M, Gokmen N, Erbayraktar S, et al. Erythropoietin prevents motor neuron apoptosis and neurologic disability in experimental spinal cord ischemic injury. Proc Natl Acad Sci U S A 2002;99 (4):2258-63. [PubMed: 11854521]

92. Gorio A, Gokmen N, Erbayraktar S, et al. Recombinant human erythropoietin counteracts secondary injury and markedly enhances neurological recovery from experimental spinal cord trauma. Proc Natl Acad Sci U S A 2002;99(14):9450-5. [PubMed: 12082184]

93. Villa P, Bigini P, Mennini T, et al. Erythropoietin selectively attenuates cytokine production and inflammation in cerebral ischemia by targeting neuronal apoptosis. J Exp Med 2003;198(6):971-5. [PubMed: 12975460]

94. Viviani B, Bartesaghi S, Corsini E, et al. Erythropoietin protects primary hippocampal neurons increasing the expression of brain-derived neurotrophic factor. J Neurochem 2005;93(2):412-21. [PubMed: 15816864]

95. Soliz J, Joseph V, Soulage C, et al. Erythropoietin regulates hypoxic ventilation in mice by interacting with brainstem and carotid bodies. J Physiol 2005;568(Pt 2):559-71. [PubMed: 16051624]

96. Springborg JB, Ma X, Rochat P, et al. A single subcutaneous bolus of erythropoietin normalizes cerebral blood flow autoregulation after subarachnoid haemorrhage in rats. Br J Pharmacol 2002;135 (3):823-9. [PubMed: 11834631]

97. Sugawa M, Sakurai Y, Ishikawa-Ieda Y, Suzuki H, Asou H. Effects of erythropoietin on glial cell development; oligodendrocyte maturation and astrocyte proliferation. Neurosci Res 2002;44(4):391403. [PubMed: 12445627]

98. Li W, Maeda Y, Yuan RR, Elkabes S, Cook S, Dowling P. Beneficial effect of erythropoietin on experimental allergic encephalomyelitis. Ann Neurol 2004;56(6):767-77. [PubMed: 15562412] 
99. Zhang J, Li Y, Cui Y, et al. Erythropoietin treatment improves neurological functional recovery in EAE mice. Brain Res 2005;1034(12):34-9. [PubMed: 15713257]

100. Arishima Y, Setoguchi T, Yamaura I, Yone K, Komiya S. Preventive effect of erythropoietin on spinal cord cell apoptosis following acute traumatic injury in rats. Spine 2006;31(21):2432-8. [PubMed: 17023852]

101. Vitellaro-Zuccarello L, Mazzetti S, Madaschi L, Bosisio P, Gorio A, De Biasi S. Erythropoietinmediated preservation of the white matter in rat spinal cord injury. Neuroscience 2007;144(3):86577. [PubMed: 17141961]

102. Shen Q, Goderie SK, Jin L, et al. Endothelial cells stimulate self-renewal and expand neurogenesis of neural stem cells. Science 2004;304(5675):1338-40. [PubMed: 15060285]

103. Wiessner C, Allegrini PR, Ekatodramis D, Jewell UR, Stallmach T, Gassmann M. Increased cerebral infarct volumes in polyglobulic mice overexpressing erythropoietin. J Cereb Blood Flow Metab 2001;21(7):857-64. [PubMed: 11435798]

104. Ogunshola OO, Djonov V, Staudt R, Vogel J, Gassmann M. Chronic excessive erythrocytosis induces endothelial activation and damage in mouse brain. Am J Physiol Regul Integr Comp Physiol 2006;290(3):R678-84. [PubMed: 16254128]

105. Ehrenreich H, Hasselblatt M, Dembowski C, et al. Erythropoietin therapy for acute stroke is both safe and beneficial. Mol Med 2002;8(8):495-505. [PubMed: 12435860]

106. Hasselblatt M, Ehrenreich H, Siren AL. The brain erythropoietin system and its potential for therapeutic exploitation in brain disease. J Neurosurg Anesthesiol 2006;18(2):132-8. [PubMed: 16628067]

107. Vaziri ND, Zhou XJ, Naqvi F, et al. Role of nitric oxide resistance in erythropoietin-induced hypertension in rats with chronic renal failure. Am J Physiol 1996;271(1 Pt 1):E113-22. [PubMed: 8760088]

108. Fukuda MN, Sasaki H, Lopez L, Fukuda M. Survival of recombinant erythropoietin in the circulation: the role of carbohydrates. Blood 1989;73(1):84-9. [PubMed: 2910371]

109. Imai N, Higuchi M, Kawamura A, et al. Physicochemical and biological characterization of asialoerythropoietin. Suppressive effects of sialic acid in the expression of biological activity of human erythropoietin in vitro. Eur J Biochem 1990;194(2):457-62. [PubMed: 2269277]

110. Dong YJ, Kung C, Goldwasser E. Receptor binding of asialoerythropoietin. J Cell Biochem 1992;48 (3):269-76. [PubMed: 1400613]

111. Erbayraktar S, Grasso G, Sfacteria A, et al. Asialoerythropoietin is a nonerythropoietic cytokine with broad neuroprotective activity in vivo. Proc Natl Acad Sci U S A 2003;100(11):6741-6. [PubMed: 12746497]

112. Wang X, Zhu C, Wang X, et al. The nonerythropoietic asialoerythropoietin protects against neonatal hypoxia-ischemia as potently as erythropoietin. J Neurochem 2004;91(4):900-10. [PubMed: 15525344]

113. Grasso G, Sfacteria A, Erbayraktar S, et al. Amelioration of spinal cord compressive injury by pharmacological preconditioning with erythropoietin and a nonerythropoietic erythropoietin derivative. J Neurosurg Spine 2006;4(4):310-8. [PubMed: 16619678]

114. Leist M, Ghezzi P, Grasso G, et al. Derivatives of erythropoietin that are tissue protective but not erythropoietic. Science 2004;305(5681):239-42. [PubMed: 15247477]

115. Hanazono Y, Sasaki K, Nitta H, Yazaki Y, Hirai H. Erythropoietin induces tyrosine phosphorylation of the beta chain of the GM-CSF receptor. Biochem Biophys Res Commun 1995;208(3):1060-6. [PubMed: 7535525]

116. Jubinsky PT, Krijanovski OI, Nathan DG, Tavernier J, Sieff CA. The beta chain of the interleukin-3 receptor functionally associates with the erythropoietin receptor. Blood 1997;90(5):1867-73. [PubMed: 9292519]

117. Scott CL, Robb L, Papaevangeliou B, Mansfield R, Nicola NA, Begley CG. Reassessment of interactions between hematopoietic receptors using common beta-chain and interleukin-3-specific receptor beta-chain-null cells: no evidence of functional interactions with receptors for erythropoietin, granulocyte colony-stimulating factor, or stem cell factor. Blood 2000;96(4):158890. [PubMed: 10942411] 
118. Brines M, Grasso G, Fiordaliso F, et al. Erythropoietin mediates tissue protection through an erythropoietin and common beta-subunit heteroreceptor. Proc Natl Acad Sci U S A 2004;101(41): 14907-12. [PubMed: 15456912]

119. Brines M, Cerami A. Emerging biological roles for erythropoietin in the nervous system. Nat Rev Neurosci 2005;6(6):484-94. [PubMed: 15928718] 


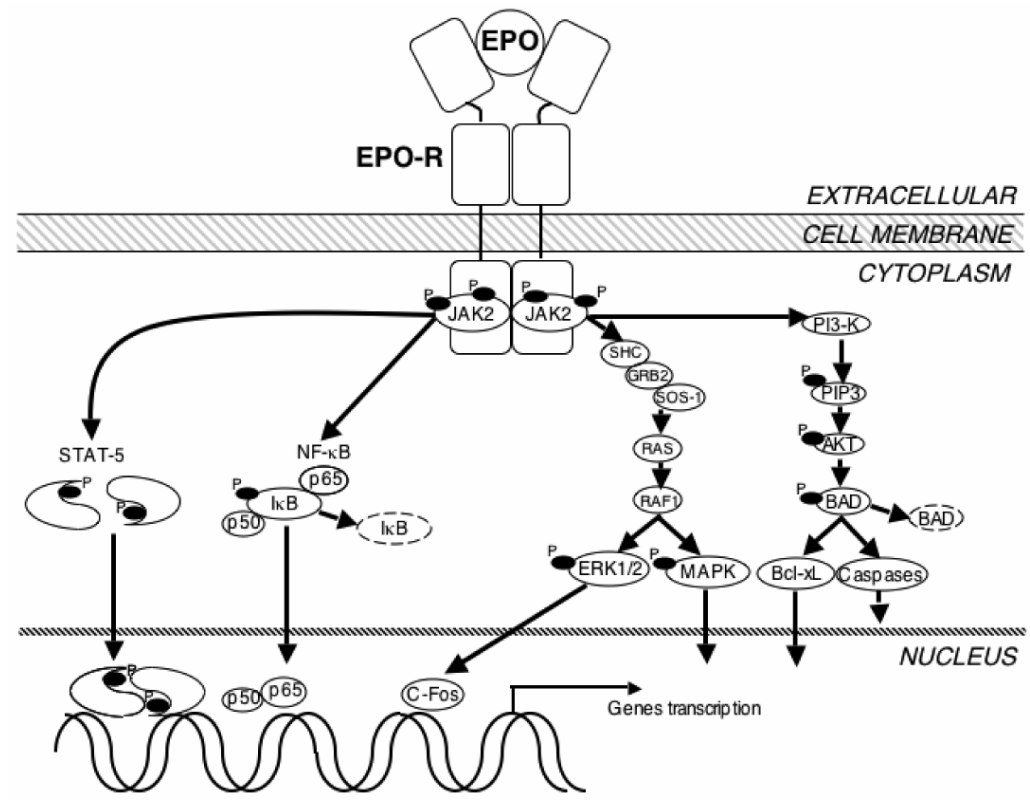

Figure 1.

EPO signaling in neural cells. In neural cells, EPO binds to the EPO-R dimmer and stimulates JAK2 kinase activity resulting in phosphorylation (P) of JAK2 and EPO-R. Activated JAK2 initiates signal transduction through several adaptor proteins such as Src homology containing protein (SHC), growth factor receptor-binding protein 2 (GRB2), son of sevenless protein-1 (SOS-1), and phosphoinositol 3-kinase (PI3-K). The downstream signaling messengers include the $\mathrm{G}$ protein (RAS), serine/threonine-specific kinase (RAF1), p38 mitogen-activated protein kinase (MAPK), extracellular response- stimulated kinase (ERK1/2), human oncogene (CFos), membrane phospholipids (phosphoinositol 3,4,5-phosphate, PIP3), protein kinase B (AKT), apoptosis inducer (BAD), anti-apoptotic protein (Bcl-xL), and the caspases. Additional signaling pathways contain signal transducer and activator of transcription 5 (STAT5) and Nuclear factor kappa B (NF- $\mathrm{B})$. All of these pathways have been found to affect the gene transcription in neural cells survive related to EPO. 


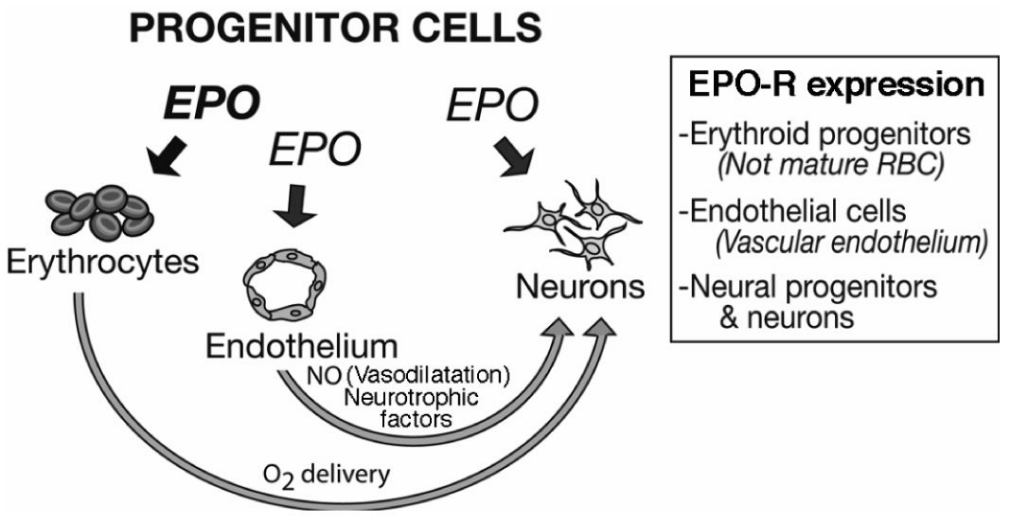

Figure 2.

Contributions of EPO activity to neuroprotection and repair. Erythroid progenitor cells, endothelial cells, neural progenitor cells and neurons express EPO-R. Direct EPO stimulation of neural progenitor cells or neurons can be regenerative or neuroprotective. Indirectly, EPO can increase oxygen delivery to the brain through stimulation of erythroid progenitor cells to increase mature red blood cell production and stimulation of endothelial cells to increase NO production. EPO stimulated endothelial cells can indirectly promote neural cell survival via production of neurotrophic factors. 


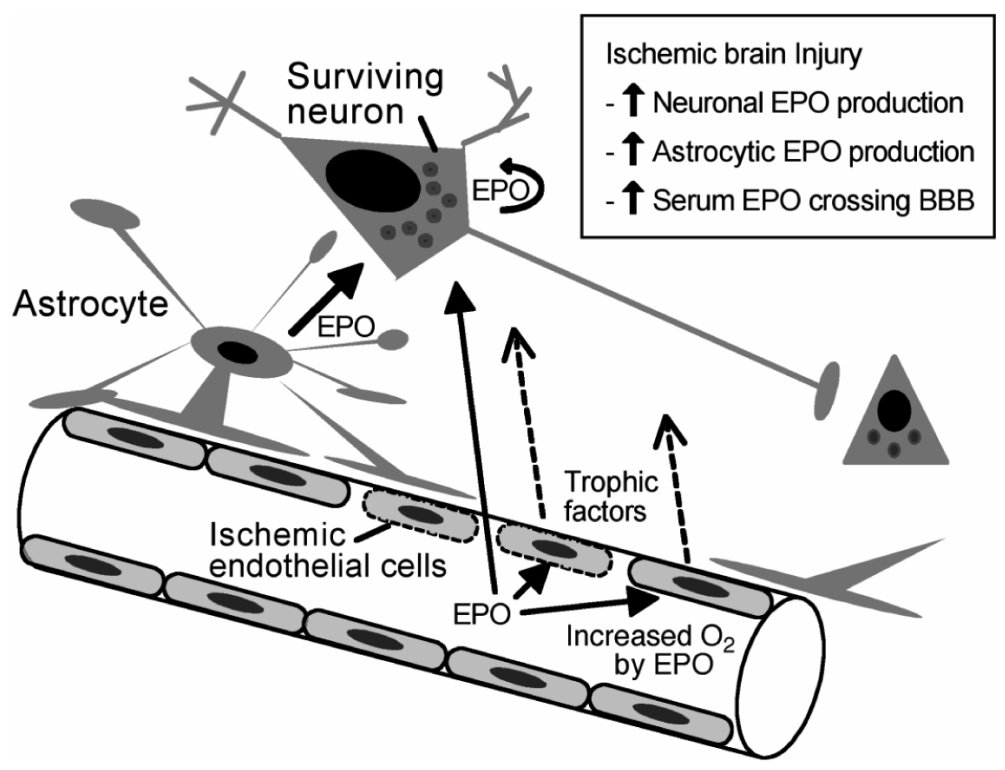

Figure 3.

EPO neuroprotection in ischemic brain injury. Neural progenitor cells and neurons can receive EPO in three ways: 1) Increased production of EPO by autocrine action or from adjacent neurons, 2) Increased production of EPO by glial cells, e.g. astrocytes, 3) Increased EPO crossing the blood- brain barrier in which the permeability is comprised during hypoxia/ ischemia. In addition, EPO may stimulate endothelial cells to secrete neurotrophic factors and hence provide indirect neuroprotection. 


\section{Table 1}

EPO Effects in Hematopoietic and Nervous Systems

\begin{tabular}{|l|l|l|}
\hline & Hematopoietic & Nervous svstem \\
\hline EPO-R & $\begin{array}{l}\text { Erythroid progenitor cells } \\
\text { (Not RBC) }\end{array}$ & $\begin{array}{l}\text { Neural progenitor cells (NPC) } \\
\text { Neurons } \\
\text { (endothelial cells) }\end{array}$ \\
\hline EPO source & $\begin{array}{l}\text { Kidney; liver } \\
\text { Hypoxia inducible }\end{array}$ & $\begin{array}{l}\text { Astrocyte; neuron } \\
\text { Hypoxia inducible }\end{array}$ \\
\hline EPO signaling & JAK2/STAT5 & $\begin{array}{l}\text { JAK2/STAT5 } \\
\text { PI3K/AKT } \\
\text { NF-KB }\end{array}$ \\
\hline EPO activity & Required CFU-E survival & $\begin{array}{l}\text { Anti-apoptotic (neuron) } \\
\text { Proliferation (NPC) }\end{array}$ \\
& Proliferation & $\begin{array}{l}\text { Neuroprotective in animal } \\
\text { models and first clinical trial in } \\
\text { humans }\end{array}$ \\
\hline Exogenous EPO & Treatment for anemia & \\
& & \\
& &
\end{tabular}

